\title{
Sistem Navigasi Quadrotor Berbasis IMU dengan Kalman Filter Tuning
}

\author{
Lasmadi \\ Departemen Teknik Elektro, Sekolah Tinggi Teknologi Adisutjipto, Indonesia \\ email: lasmadi3@gmail.com
}

\begin{abstract}
Abstrak- Sistem navigasi pada quadrotor penting untuk menjaga kestabilan dan menentukan posisinya ketika terbang secara autonomous. GPS dapat memberikan pengukuran posisi, tetapi memiliki keterbatasan di lingkungan yang menyebabkan sinyal terhalang dan tidak dapat memberikan informasi orientasi. Penelitian ini bertujuan merancang sistem navigasi quadrotor berbasis sensor IMU menggunakan Kalman filter dengan model state-space. Model sistem dikembangkan menggunakan perangkat lunak Matlab. Kalman filter dikembangkan dengan tuning parameter kovarian untuk mengkompensasi efek derau dan mendapatkan estimasi pengukuran rotasi dan translasi quadrotor yang optimal. Hasil pengujian menunjukkan bahwa model sistem dapat memberikan estimasi pergerakan orientasi dan translasi quadrotor. Ketika diuji di dalam ruangan, sistem dapat memberikan akurasi pengukuran di atas $90 \%$.
\end{abstract}

Kata Kunci: Kalman-filter, navigasi, IMU, quadrotor, state-space

\section{Pendahuluan}

Perkembangan teknologi robotika khususnya robot terbang sangat pesat pada dekade terakhir ini. Salah satu jenis robot terbang yang populer adalah quadrotor. Quadrotor merupakan salah satu jenis Unmaned Aerial Vehicle (UAV) yang menggunakan penggerak empat rotor. Beberapa kelebihan quadrotor dibanding jenis UAV lainnya, diantaranya keandalannya dalam bermanuver, tidak membutuhkan tempat luas untuk mendarat, dapat lepas landas secara vertikal [1], mekaniknya sederhana dan kuat [2] serta aplikasinya sangat luas.

Sistem navigasi pada quadrotor secara khusus penting untuk menjaga kestabilan quadrotor di lingkungan indoor yang kompleks [3]. Untuk dapat bergerak secara otonom di area tertentu, robot harus memiliki kemampuan untuk menentukan posisinya [4] dan orientasinya. Global Positioning Systems (GPS) dapat memberikan pengukuran posisi yang akurat [5], namun memiliki keterbatasan dalam lingkungan tertentu, seperti di dalam gedung, lingkungan urban, dan di bawah air. Selain itu, untuk mendapatkan estimasi pengukuran dalam beberapa centimeter tidak dapat dilakukan dengan GPS [6].

Pada umumnya, quadrotor memiliki keterbatasan sumber daya baterai. Untuk mengatasinya, digunakan sistem navigasi inersia menggunakan sensor inertial measurement unit (IMU) berbasis teknologi micro-electro mechanical systems (MEMS) yang membutuhkan daya rendah, mempunyai bentuk kecil, dan ringan [7]. Namun, MEMS memiliki derau yang besar, akurasinya rendah, mempunyai bias error dan tidak memberikan data estimasi posisi secara langsung [8]. Oleh karena itu, digunakan Kalman filter untuk meminimalkan varian kesalahan dari estimasi pengukuran. Kalman filter memiliki tingkat komputasi yang kecil dan merupakan estimator yang optimal [9].

Perancangan sistem navigasi berbasis sensor inersia telah dilakukan oleh Yadav \& Bleakley [10] menggunakan dua sensor IMU dengan metode two stage Kalman filter. Metode ini dapat memperbaiki akurasi estimasi posisi sekitar $30 \%$ bila dibanding metode dead reckoning konvensional. Namun, metode two stage dengan strategi penempatan dua sensor sulit dilakukan pada AR Drone 2.0 dengan IMU tunggal sudah terpasang onboard pada bodi quadrotor. Sementara itu, Safitri dan Wijaya [11] telah menggunakan metode zero velocity compensator (ZVC) dan Kalman filter untuk estimasi posisi. Metode ZVC mengasumsikan kecepatan dan percepatan harus nol saat sensor dalam keadaan stasioner.

Penelitian yang dilakukan oleh Shen et.al. [12] telah menggunakan scanning laser range finder (LRF) untuk estimasi posisi dan orientasi sebuah quadrotor. Penelitian tersebut menggunakan metode simultaneous localization and mapping (SLAM) dan Kalman filter. Penggunaan LRF sebagai sistem navigasi juga telah dilakukan oleh Bry et.al ${ }^{[13]}$ yang diterapkan pada UAV fixed-wing. Dalam penelitian tersebut, digunakan sensor planar LRF dan IMU menggunakan algoritma Gaussian Particle Filter (GPF). Perancangan sistem navigasi dengan multi sensor dapat ditemukan dalam [14] yang menggunakan sensor LRF, optical flow camera, IMU, dan barometer untuk navigasi wahana dalam ruangan. Menurut Goh et.al. [5], semakin banyak penggunaan sensor akan menambah beban komputasi.

Penelitian ini menyajikan pengembangan sistem navigasi berbasis sensor IMU menggunakan Kalman filter dengan tuning parameter kovarian untuk estimasi pergerakan quadrotor. Model dirancang dengan pendekatan dinamika gerak sederhana dalam bentuk persamaan state space menggunakan perangkat lunak Matlab. Hasil penelitian ini diharapkan dapat memberikan kontribusi pada pengembangan sistem navigasi berbasis IMU untuk estimasi pergerakan quadrotor.

\section{Metodologi Penelitian}

\subsection{Quadrotor AR Drone 2.0 dan Perangkat IMU}

Quadrotor yang digunakan sebagai objek penelitian adalah AR Drone 2.0 yang telah dilengkapi IMU dan sensor 
lainnya. Dalam pengoperasiannya, quadrotor AR Drone 2.0 didukung oleh hotspot wi-fi sehingga kontrol fisik quadrotor dapat dilakukan dengan ponsel pintar atau laptop. Spesifikasi perangkat elektronis (electronic assistance) AR Drone 2.0 ditunjukkan pada Tabel 1.

Tabel 1. Spesifikasi Perangkat Elektronis Quadrotor [15]

\begin{tabular}{ll}
\hline \multicolumn{1}{c}{ Perangkat } & \multicolumn{1}{c}{ Spesifikasi } \\
\hline \hline Prosesor & $\begin{array}{l}\text { ARM Cortex A8 1 GHz 32-bit processor } \\
\text { with DSP video 800 MHz TMS320DMC64x }\end{array}$ \\
\hline Sistem Operasi & Linux 2.6.32 \\
\hline RAM & DDR2 1 GB pada 200 MHz \\
\hline Wi-fi & b g n \\
\hline Giroskop & 3 aksis, akurasi 2,000\%sekon \\
\hline Akselerometer & 3 aksis, akurasi +/- 50 mg \\
\hline Magnetometer & 3 aksis, akurasi 6 \\
\hline Kamera Vertikal & QVGA 60 FPS untuk mengukur ketinggian \\
\hline
\end{tabular}

\subsection{Pemrosesan Data Sensor IMU}

Data sensor IMU (akselerometer, giroskop) pada AR Drone dibaca pada saat quadrotor terhubung dengan laptop melalui jaringan wi-fi. Pembacaan data pada laptop menggunakan program Robot Operating System (ROS) versi fuerte dengan package ardrone_autonomy dan sensor_msgs yang di-install diatas sistem operasi Linux Ubuntu precise 12.04 LTS. Data gerakan orientasi atau translasi didapatkan ketika quadrotor digerakkan dengan tangan pada sumbu tertentu. Pada saat quadrotor digerakkan, data dibaca di laptop. Proses pembacaan data dimulai dan diakhiri dengan menekan tombol tertentu pada keyboard laptop. Data sensor yang dibaca pada ROS disimpan ke dalam format xls dengan menggunakan bahasa C. Kemudian, secara offline data diolah menggunakan Matlab. Skema pembacaan data dari quadrotor dan pengolahan data ditunjukkan pada diagram blok Gambar 1.
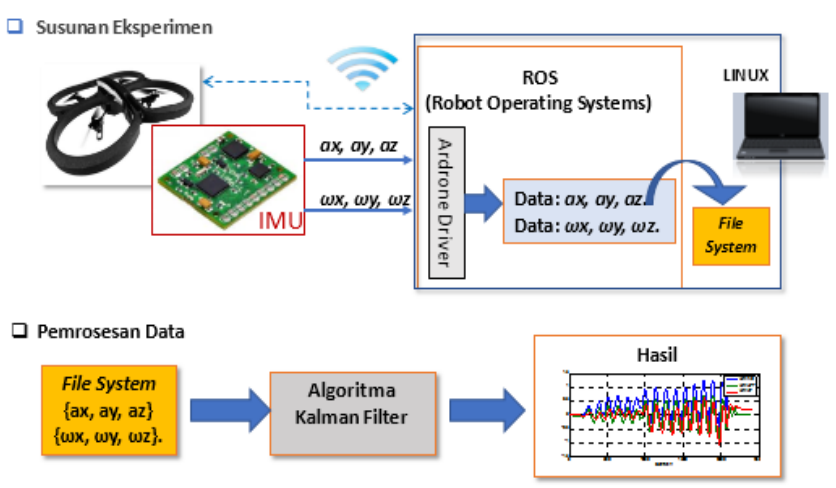

Gambar 1. Set-Up Eksperimen dan Pemrosesan Data

\subsection{Algoritma Kalman Filter}

Bentuk persamaan algoritma Kalman filter meliputi dua tingkat, yaitu update waktu atau prediksi dan update pengukuran atau koreksi. Persamaan prediksi ditunjukkan pada persamaan (1) dan (2).

$$
\begin{gathered}
\hat{x}_{\bar{k}}=A \hat{x}_{k-1}+B u_{k} \\
P_{\bar{k}}=A P_{k-1} A^{T}+Q_{k}
\end{gathered}
$$

Kemudian, persamaan koreksi diberikan oleh persamaan (3), (4), dan (5).

$$
\begin{gathered}
x_{k}=\hat{x}_{\bar{k}}+K_{k}\left(\mathrm{z}_{k}-C \hat{x}_{\bar{k}}\right) \\
P_{k}=\left(I-K_{k} C\right) P_{\bar{k}} \\
K_{k}=P_{\bar{k}} C^{T}\left(C P_{\bar{k}} C^{T}+R_{k}\right)^{-1} .
\end{gathered}
$$

dengan, $A, B$, dan $C$ masing-masing adalah state, $\hat{x}_{\bar{k}}$ adalah vektor state prediksi pada waktu $k, P_{\bar{k}}$ adalah matriks kovarian prediksi pada waktu $k$, dan $P_{k-1}$ adalah matriks kovarian pada waktu $k-1$ (waktu sebelum $k$ ). Kemudian, $x_{k}$ sebagai vektor state koreksi pada waktu $k, K$ sebagai Kalman gain, $\mathrm{z}_{k}$ sebagai output pengukuran pada waktu $k$, dan $I$ adalah matriks identitas. Sementara itu, $Q_{k}$ dan $R_{k}$ masingmasing adalah matriks kovarian derau proses dan matriks kovarian derau pengukuran. Dalam penelitian ini, nilai $Q$ dan $R$ ditentukan dengan percobaan beberapa kali sampai didapatkan estimasi yang optimal, dalam hal ini diistilahkan tuning.

Diagram blok sistem dan Kalman filter dengan derau proses $w_{k}$ dan derau pengukuran $\delta_{k}$ dapat ditunjukkan pada Gambar 2.

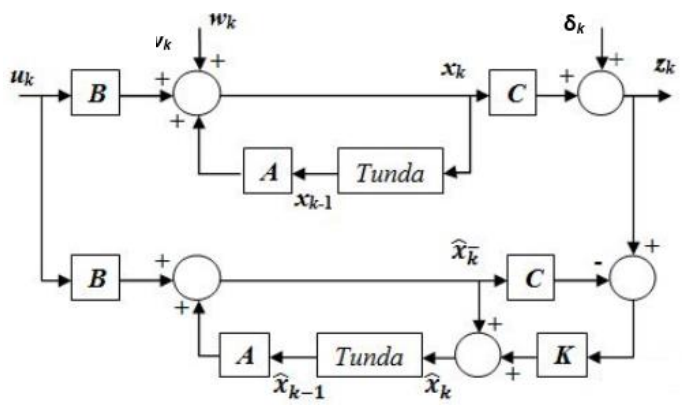

Gambar 2. Diagram Blok Sistem dengan Kalman Filter

Algoritma rekursif Kalman filter dapat digambarkan sebagaimana Gambar 3.

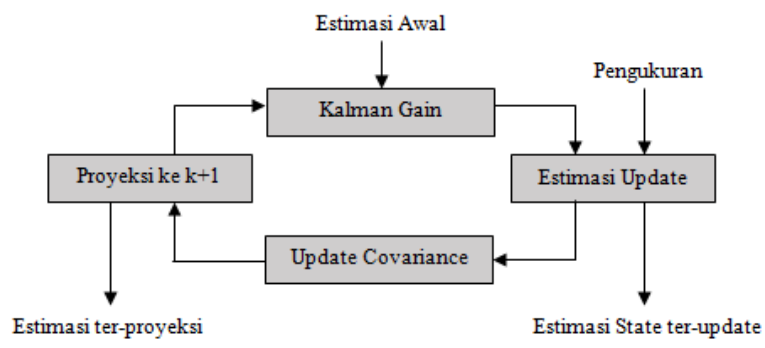

Gambar 3. Algoritma Rekursif Kalman Filter

\subsection{Perancangan Kalman Filter untuk Giroskop}

Pada bagian ini, Kalman filter dirancang sebagai estimator sudut dari data pengukuran sensor giroskop. Persamaan sistem untuk menghitung sudut orientasi (rotasi) dapat diturunkan dari kecepatan sudut $(\omega)$ menggunakan persamaan (6) dan (7) [16].

$$
\begin{gathered}
\Omega_{k}=\Omega_{k-1}+\left(\omega_{k-1}-g_{b k-1}\right) T \\
g_{b k}=g_{b k-1}
\end{gathered}
$$


dengan $\Omega_{k}$ adalah notasi sudut pada waktu $k, \Omega_{k-1}$ adalah notasi sudut pada waktu $k-1$ (waktu sebelum $k$ ), $\omega_{k-1}$ adalah data kecepatan sudut sebelum waktu $k, \mathrm{~g}_{b k}$ adalah bias giroskop, $g_{b k-1}$ adalah data bias giroskop sebelum waktu $k$ dan $T$ adalah periode sampling. Informasi dari giroskop dapat dipengaruhi oleh kesalahan tegangan bias, sehingga perlu diperhitungkan dalam persamaan sistem untuk mengoreksi nilai kecepatan sudut.

Didasarkan pada persamaan (6) dan (7), vektor state setiap aksis- $i(i \in\{\mathrm{x}, \mathrm{y}, \mathrm{z}\})$ pada giroskop berisi sudut dan bias giroskop sebagaimana persamaan (8).

$$
x_{G k}=\left[\begin{array}{ll}
\Omega_{k} & g_{b k}
\end{array}\right]^{T}
$$

dengan $x_{G k}$ adalah vektor state pada waktu $k$ untuk data sensor giroskop, semuanya dalam koordinat sensor.

Algoritma Kalman filter untuk data giroskop mengasumsikan bahwa keadaan suatu sistem pada waktu $k$ berevolusi dari keadaan sebelumnya pada waktu $k-1$ sesuai dengan persamaan (9) ${ }^{[8]}$.

$$
x_{G k}=A_{G} x_{G k-1}+B_{G} u_{G k}+\grave{\mathrm{w}}_{k}
$$

dengan $A_{G}$ adalah matriks transisi state pada waktu $k$ - 1 yang mempengaruhi state sistem pada waktu $k, B_{G}$ adalah matriks input kontrol, $u_{G k}$ adalah vektor input kontrol, dalam hal ini kecepatan sudut setiap aksis- $i\left(\omega_{i}\right)$, dan $\grave{\mathrm{w}}_{k}$ adalah vektor yang berisi derau proses untuk setiap parameter dalam vektor state. Derau proses diasumsikan terdistribusi normal dengan rata-rata nol dengan kovarian yang diberikan oleh matriks kovarian $Q_{G}$

Persamaan (6) dapat dinyatakan dalam bentuk sebagaimana persamaan (10),

$$
\Omega_{k}=\Omega_{k-1}+T \omega_{k-1}-T g_{b k-1} \text {. }
$$

Berdasarkan persamaan (8) dan (10) matriks $A_{G}, B_{G}$ dan matriks kovarian $Q_{G}$ untuk persamaan (9) dapat dimodelkan dalam state space sebagai berikut.

$$
\begin{gathered}
A_{G}=\left[\begin{array}{ccccccc}
1 & -T & & 0 & 0 & 0 & 0 \\
0 & 0.01 & & 0 & 0 & 0 & 0 \\
0 & 0 & 1 & -T & 0 & 0 \\
0 & 0 & 0 & 0.01 & 0 & 0 \\
0 & 0 & 0 & 0 & 1 & -T \\
0 & 0 & 0 & 0 & 0 & 0.01
\end{array}\right], B_{G}=\left[\begin{array}{c}
T \\
0 \\
T \\
0 \\
T \\
0
\end{array}\right], \\
Q_{G}=\left[\begin{array}{cccccc}
\gamma & 0 & 0 & 0 & 0 & 0 \\
0 & \gamma & 0 & 0 & 0 & 0 \\
0 & 0 & \gamma & 0 & 0 & 0 \\
0 & 0 & 0 & \gamma & 0 & 0 \\
0 & 0 & 0 & 0 & \gamma & 0 \\
0 & 0 & 0 & 0 & 0 & \gamma
\end{array}\right],
\end{gathered}
$$

dengan $\gamma$ adalah nilai parameter tuning. Pada kasus ini, $\gamma$ ditentukan dengan percobaan. Berdasarkan percobaan, nilai $\gamma$ yang optimal adalah 0,000617 .

Untuk mendapatkan estimasi state atau variabel output pengukuran estimasi orientasi dari data giroskop, dapat digunakan persamaan (11) [8].

$$
\mathrm{z}_{G k}=C_{G} x_{G k}+\mathrm{d}_{k}
$$

dengan $\mathrm{Z}_{G k}$ adalah vektor pengukuran pada waktu $k$, dalam kasus ini adalah sudut orientasi, $C_{G}$ adalah matriks transisi setiap aksis- $i$ pada giroskop dan $d_{k}$ adalah vektor yang berisi derau pengukuran untuk setiap pengamatan dalam vektor pengukuran. Sebagaimana derau proses, derau pengukuran diasumsikan terdistribusi normal dengan rata-rata nol dengan kovarian yang diberikan oleh matriks $R_{G}$. Matriks $C_{G}$ dan $R_{G}$ ditentukan sebagai berikut,

$C_{G}=\left[\begin{array}{cccccc}1 & 0 & 0 & 0 & 0 & 0 \\ 0 & 0 & 1 & 0 & 0 & 0 \\ 0 & 0 & 0 & 0 & 1 & 0\end{array}\right], R_{G}=\operatorname{cov}\left[\begin{array}{ccc}\omega_{x} & 0 & 0 \\ 0 & \omega_{y} & 0 \\ 0 & 0 & \omega_{z}\end{array}\right]$

Derau proses dan derau pengukuran diasumsikan tidak berkorelasi satu sama lain. Dengan asumsi ini, matriks kovarian $Q_{G}$ dan $R_{G}$ masing-masing dapat dinyatakan sebagaimana persamaan (12) dan (13).

$$
\begin{aligned}
Q_{G} & =E\left[\grave{\mathrm{w}}_{k} \grave{\mathrm{w}}_{k}{ }^{T}\right] \\
R_{G} & =E\left[\mathrm{~d}_{k} \mathrm{~d}_{k}{ }^{T}\right] .
\end{aligned}
$$

\subsection{Perancangan Kalman Filter untuk Akselerometer}

Untuk mendapatkan estimasi pergeseran posisi translasi, digunakan data pengukuran sensor akselerometer. Persamaan pergeseran translasi, kecepatan, dan percepatan dapat dinyatakan dengan persamaan (14), (15) dan (16).

$$
\begin{gathered}
D_{k}=D_{k-1}+v_{k-1} T+\left(a_{k-1}-a_{b k-1}\right) \frac{1}{2} T^{2} \\
v_{k}=v_{k-1}+\left(a_{k-1}-a_{b k-1}\right) T \\
a_{k}=a_{k-1}
\end{gathered}
$$

dimana, $D_{k}$ adalah notasi jarak pergerakan translasi pada waktu $k, v$ adalah notasi kecepatan pada waktu $k, v_{k-1}$ adalah notasi kecepatan pada waktu $k-1$ (waktu sebelum $k$ ), $a_{k}$ sebagai percepatan linier pada waktu $k, a_{k-1}$ sebagai percepatan pada waktu $k-1, a_{b}$ sebagai bias akselerometer, $a_{b k-1}$ sebagai notasi bias pada waktu $k-1$, dan $T$ adalah periode sampling. Informasi dari akselerometer dapat dipengaruhi oleh kesalahan tegangan bias, sehingga perlu diperhitungkan dalam persamaan sistem untuk mengoreksi nilai percepatan.

Pada bagian ini, Kalman filter dirancang sebagai estimator posisi dari data sensor akselerometer. Didasarkan pada persamaan (14), (15) dan (16), vektor state setiap aksis$j(j \in\{\mathrm{x}, \mathrm{y}\})$ pada akselerometer berisi jarak pergerakan translasi, kecepatan dan bias akselerometer sebagaimana persamaan (17).

$$
x_{A k}=\left[\begin{array}{lll}
D_{k} & v_{k} & a_{b}
\end{array}\right]^{T}
$$

Dengan $x_{k}$ adalah vektor state pada waktu $k$ untuk data sensor akselerometer, semuanya dalam koordinat sensor.

Model sistem dirancang dapat memberikan estimasi jarak pergeseran translasi arah $\mathrm{X}$ atau Y. Dalam kasus ini, arah $\mathrm{Z}$ yang berkaitan dengan arah ketinggian terhadap 
ground tidak diperhitungkan atau diabaikan dalam pengukuran.

Algoritma Kalman filter pada data akselerometer untuk estimasi gerak translasi dapat dinyatakan sebagaimana persamaan (18).

$$
x_{A k}=A_{A} x_{A k-1}+B_{A} u_{A k}+\xi_{k}
$$

dengan $A_{A}$ adalah matriks transisi state pada waktu $k$ - $l$ yang mempengaruhi state sistem pada waktu $k, B_{A}$ adalah matriks input kontrol, $u_{A k}$ adalah vektor input kontrol, dalam hal ini percepatan linier setiap aksis- $j\left(a_{j}\right)$, dan $\xi_{k}$ adalah vektor yang berisi derau proses untuk setiap parameter dalam vektor state. Derau proses diasumsikan terdistribusi normal ratarata nol dengan kovarian yang diberikan oleh matriks $Q_{A}$.

Persamaan (14) dan (15) dapat dinyatakan dalam bentuk sebagaimana persamaan (19) dan (20),

$$
\begin{gathered}
D_{k}=D_{k-1}+v_{k-1} T+\frac{1}{2} T^{2} a_{k-1}-\frac{1}{2} T^{2} a_{b k-1} \\
v_{k}=v_{k-1}+T a_{k-1}-T a_{b k-1}
\end{gathered}
$$

Berdasarkan persamaan (17), (19) dan (20) matriks $A_{A}, B_{A}$ dan matriks kovarian $Q_{A}$ untuk persamaan (18) dapat dimodelkan dalam state space sebagai berikut.

$$
\begin{gathered}
A_{A}=\left[\begin{array}{ccccccc}
1 & T & -\frac{1}{2} T^{2} & 0 & 0 & 0 \\
0 & 1 & -T & 0 & 0 & 0 \\
0 & 0 & 1 & 0 & 0 & 0 \\
0 & 0 & 0 & 1 & T & -\frac{1}{2} T^{2} \\
0 & 0 & 0 & 0 & 1 & -T \\
0 & 0 & 0 & 0 & 0 & 1
\end{array}\right], B_{A}=\left[\begin{array}{c}
\frac{1}{2} T^{2} \\
T \\
0 \\
\frac{1}{2} T^{2} \\
T \\
0
\end{array}\right], \\
Q_{A}=\left[\begin{array}{cccccc}
\beta & 0 & 0 & 0 & 0 & 0 \\
0 & \beta & 0 & 0 & 0 & 0 \\
0 & 0 & \beta & 0 & 0 & 0 \\
0 & 0 & 0 & \beta & 0 & 0 \\
0 & 0 & 0 & 0 & \beta & 0 \\
0 & 0 & 0 & 0 & 0 & \beta
\end{array}\right]
\end{gathered}
$$

dengan $\beta$ adalah parameter tuning. Pada kasus ini, $\beta$ ditentukan dengan percobaan. Berdasarkan percobaan, nilai $\beta$ optimal adalah 0,00617 .

Model persamaan untuk mendapatkan estimasi state atau variabel output pengukuran estimasi translasi dari data akselerometer, ditunjukkan pada persamaan (21).

$$
\mathrm{Z}_{A k}=C_{A} x_{A k}+\epsilon_{k} \text {, }
$$

dengan $\mathrm{Z}_{A k}$ adalah vektor pengukuran pada waktu $k$, dalam kasus ini adalah jarak pergerakan translasi, $C_{A}$ adalah matriks transisi setiap aksis- $j$ pada akselerometer dan $\epsilon_{k}$ adalah vektor derau pengukuran untuk setiap pengamatan dalam vektor pengukuran. Sebagaimana derau proses, derau pengukuran diasumsikan terdistribusi normal rata-rata nol dengan kovarian yang diberikan oleh matriks $R_{A}$. Matriks $C_{A}$ dan $R_{A}$ ditentukan sebagai berikut,

$$
C_{A}=\left[\begin{array}{llllll}
1 & 0 & 0 & 0 & 0 & 0 \\
0 & 0 & 0 & 1 & 0 & 0
\end{array}\right], R_{A}=\operatorname{cov}\left[\begin{array}{ll}
a_{x} & 0 \\
0 & a_{y}
\end{array}\right]
$$

Derau proses dan derau pengukuran diasumsikan tidak berkorelasi satu sama lain. Dengan asumsi ini, matriks kovarian $Q_{A}$ dan $R_{A}$ dapat dinyatakan sebagaimana persamaan (22) dan (23).

$$
\begin{aligned}
& Q_{A}=E\left[\xi_{k} \xi_{k}^{T}\right] \\
& R_{A}=E\left[\epsilon_{k} \epsilon_{k}^{T}\right] .
\end{aligned}
$$

\section{Hasil dan Pembahasan}

\subsection{Estimasi Sudut Orientasi}

Data keluaran sensor giroskop merupakan data kecepatan sudut. Metode state space dan Kalman filter digunakan untuk mendapatkan estimasi sudut orientasi dari masukan data kecepatan sudut. Dalam penelitian ini, data kecepatan sudut didapatkan dengan memutar (menggoyang) rangka quadrotor pada aksis yang berkaitan.

Pengujian estimasi sudut roll dilakukan dengan memutar rangka quadrotor terhadap aksis $-\mathrm{x}$ selama kurang lebih dua menit dengan sudut acak. Pengujian ini dilakukan untuk melihat keluaran sistem terhadap masukan perubahan gerak orientasi yang bervariasi pada aksis-x. Hasil pengujian estimasi sudut roll dapat ditunjukkan pada Gambar 4 dan Gambar 5.

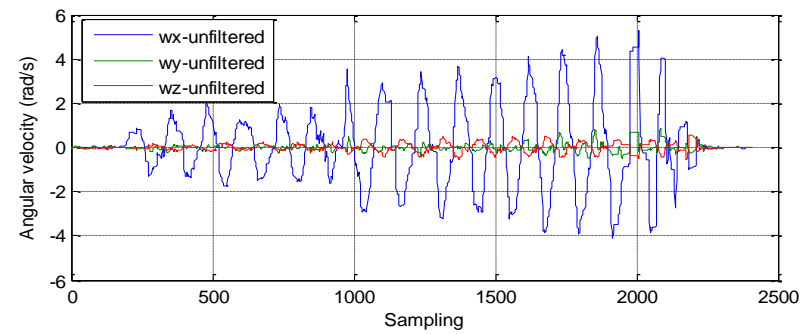

Gambar 4. Grafik Kecepatan Sudut Rotasi Aksis-x

Gambar 4 menunjukkan grafik kecepatan sudut (rad) saat rangka diputar dinamis terhadap aksis- $x$ dengan arah berbeda sebelum melewati filter. Data yang terbaca adalah kecepatan pada ketiga aksis. Namun, pengaruh gaya terbesar ada di aksis- $x$ sehingga data kecepatan sudut pada aksis- $X$ terlihat paling besar. Data kecepatan sudut pada aksis-y dan aksis-z tidak sepenuhnya nol karena masih ada sedikit pengaruh gaya pada aksis-y dan aksis-z.

Gambar 5 menunjukkan grafik kecepatan sudut pada aksis-x sebelum dan setelah dilakukan penapisan (filtering). Sebelum dilakukan penapisan, terlihat derau paku-paku (spikes) pada data yang dapat mempengaruhi hasil estimasi. Setelah dilakukan penapisan, spikes pada data dapat dihilanglan dan grafik terlihat lebih smooth (warna merah). Hal ini dapat dilihat pada Gambar 5.

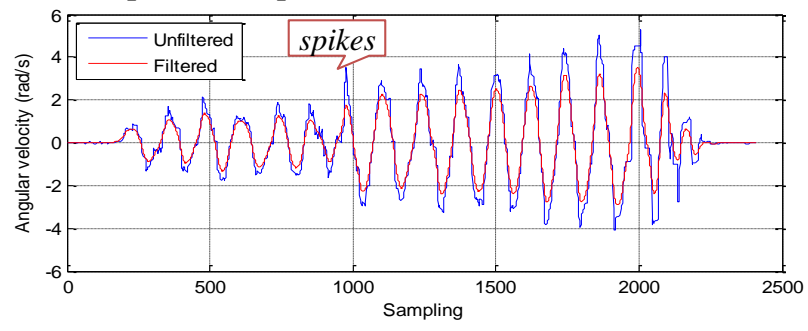

Gambar 5. Grafik Kecepatan Sudut $\omega_{\mathrm{x}}$ 


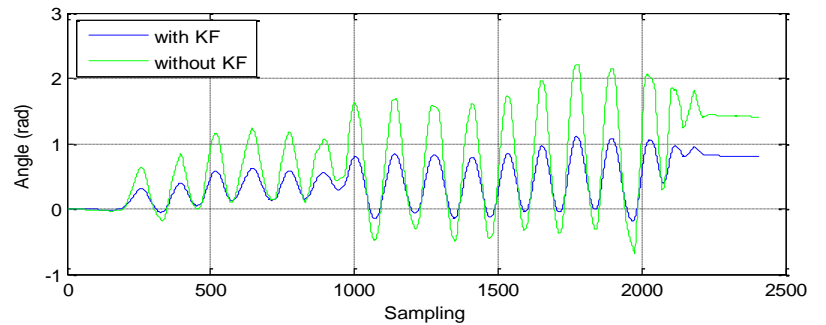

Gambar 6. Grafik Estimasi Sudut Roll

Gambar 6 menunjukkan grafik hasil estimasi sudut roll. Pengujian estimasi dilakukan dengan menggunakan metode Kalman Filter (KF) dan metode integral langsung (tanpa $\mathrm{KF}$ ). Berdasarkan pengujian, masing-masing metode dapat memberikan estimasi sudut roll terhadap perubahan gerak (sudut) masukan yang bervariasi. Ketepatan estimasi dalam pengujian ini belum diukur karena perubahan gerak diberikan secara acak. Namun, perbedaan estimasi masingmasing metode dapat dilihat dari grafik. Grafik estimasi sudut roll dengan metode KF terlihat lebih smooth bila dibandingkan dengan tanpa KF. Seperti terlihat pada Gambar 6, grafik akan terlihat semakin meningkat dari posisi sumbu nol seiring bertambahnya waktu sehingga terjadi kesalahan drift. Estimasi sudut roll dengan metode $\mathrm{KF}$ cenderung memiliki kesalahan drift lebih kecil dibanding tanpa KF.

Pengujian estimasi sudut pitch dilakukan dengan memutar rangka quadrotor terhadap aksis-y selama kurang lebih dua menit dengan sudut acak. Pengujian ini dilakukan untuk melihat keluaran sistem terhadap masukan perubahan gerak orientasi yang bervariasi pada aksis-y. Hasil pengujian estimasi sudut pitch dapat ditunjukkan pada Gambar 7 dan Gambar 8.

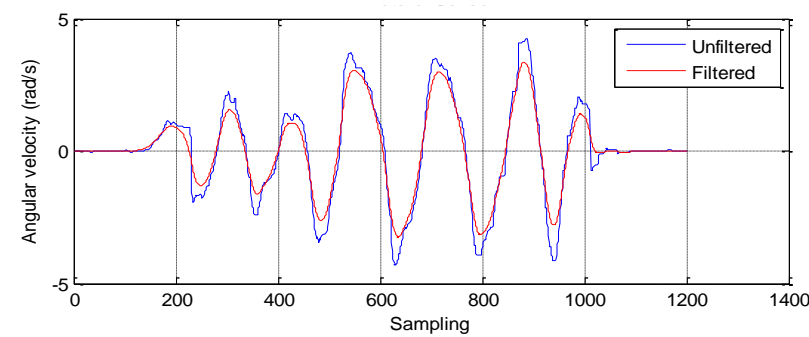

Gambar 7. Grafik Kecepatan Sudut $\omega_{\mathrm{y}}$

Gambar 7 menunjukkan grafik kecepatan sudut (rad) saat rangka diputar secara dinamis pada aksis-y sebelum dan setelah melewati filter. Kecepatan sudut pada aksis-x dan aksis-z mendekati nol (tidak ditunjukkan pada gambar) karena pengaruh gaya terbesar ada di aksis-y. Sebelum dilakukan penapisan, terlihat spikes pada data sensor. Namun, setelah dilakukan penapisan, spikes pada data dapat dihilangkan dan grafik terlihat lebih smooth.

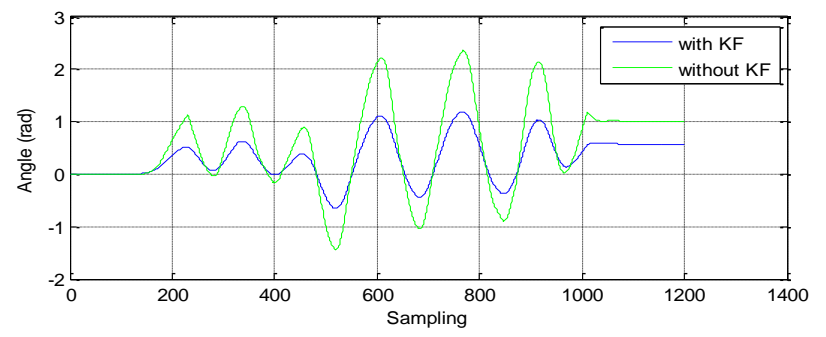

Gambar 8. Grafik Estimasi Sudut Pitch
Gambar 8 menunjukkan grafik hasil estimasi sudut pitch. Berdasarkan pengujian, metode KF dan integral langsung dapat memberikan estimasi sudut pitch terhadap perubahan sudut masukan yang bervariasi. Ketepatan estimasi dalam pengujian ini belum diukur karena perubahan gerak diberikan secara acak. Namun, perbedaan estimasi masingmasing metode dapat dilihat dari grafik. Grafik estimasi sudut pitch dengan metode KF terlihat lebih smooth bila dibandingkan tanpa KF. Seperti terlihat pada Gambar 8, terjadi kesalahan drift seiring bertambahnya waktu. Namun, estimasi sudut pitch dengan metode KF cenderung memiliki kesalahan drift lebih kecil dibanding tanpa KF.

Kemudian, pengujian estimasi sudut yaw dilakukan dengan memutar rangka quadrotor terhadap aksis-z selama kurang lebih dua menit dengan sudut acak. Pengujian ini dilakukan untuk melihat keluaran sistem terhadap masukan perubahan gerak orientasi yang bervariasi pada aksis-z. Hasil pengujian ini dapat ditunjukkan pada Gambar 9 dan Gambar 10 .

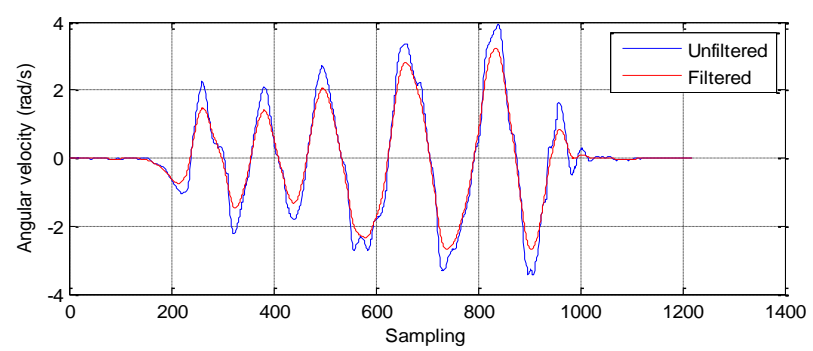

Gambar 9. Grafik Kecepatan Sudut $\omega_{z}$

Gambar 9 menunjukkan grafik kecepatan sudut (rad) saat rangka diputar pada aksis-z sebelum dan setelah melewati filter. Kecepatan sudut pada aksis-x dan aksis-y mendekati nol (tidak ditunjukkan pada gambar) karena pengaruh gaya terbesar ada di aksis-z. Sebelum dilakukan penapisan, terlihat spikes pada data sensor. Kemudian, setelah dilakukan penapisan, spikes dapat dihilangkan dan grafik terlihat lebih smooth.

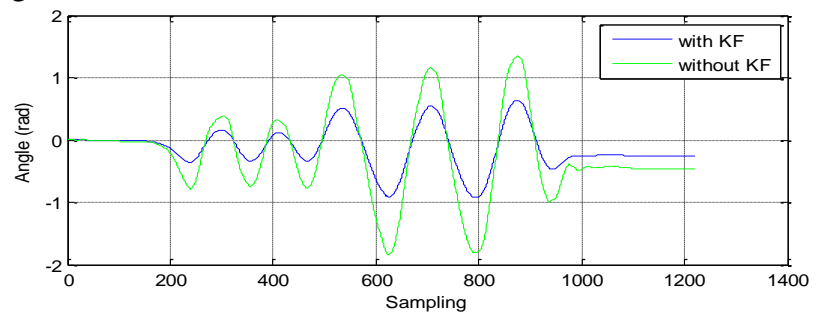

Gambar 10. Grafik Estimasi Sudut Yaw

Gambar 10 menunjukkan grafik hasil estimasi sudut yaw. Berdasarkan pengujian, metode KF dan integral langsung dapat memberikan estimasi sudut yaw terhadap perubahan sudut masukan yang bervariasi. Ketepatan estimasi dalam pengujian ini belum diukur karena perubahan gerak diberikan secara acak. Namun, perbedaan estimasi masingmasing metode dapat dilihat dari grafik. Grafik estimasi sudut yaw dengan metode KF terlihat lebih smooth bila dibandingkan tanpa KF.

Untuk menguji akurasi estimasi pengukuran, rangka quadrotor diputar terhadap aksis-X, aksis-y, dan aksis-z secara bergantian dengan sudut masing-masing $0,785 \mathrm{rad}$ 
$\left(45^{\circ}\right)$ terhadap sumbu horisontal. Pengujian ini dilakukan untuk menguji ketepatan estimasi model terhadap masukan orientasi (sudut) pada aksis tertentu.

Pengujian estimasi sudut roll $45^{\circ}$ dilakukan dengan memutar rangka quadrotor terhadap aksis- $\mathrm{x}$ sebesar $45^{\circ}$ dimulai dari posisi $0^{\circ}$. Hasil pengujian estimasi sudut roll dapat ditunjukkan pada Gambar 11 dan Gambar 12.

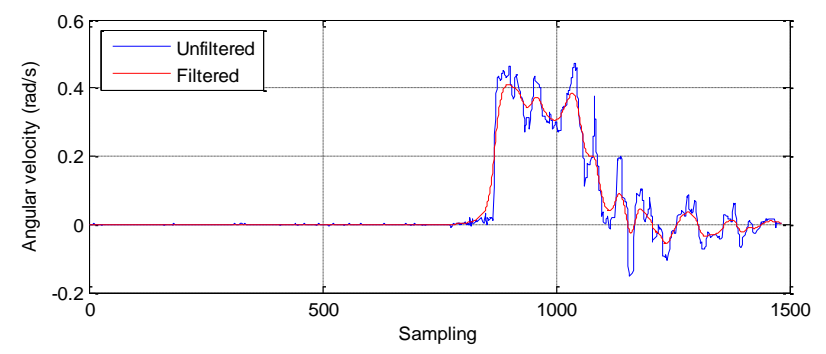

Gambar 11. Grafik Kecepatan Sudut $\omega_{\mathrm{x}}$ Rotasi $45^{\circ}$

Gambar 11 menunjukkan grafik kecepatan sudut (rad) saat rangka diputar $45^{\circ}$ pada aksis- $x$ sebelum dan setelah melewati filter. Kecepatan sudut pada aksis-y dan aksis-z diabaikan karena pengaruh gaya terbesar ada di aksis-x. Seperti dapat dilihat pada Gambar 11, sebelum dilakukan penapisan, terlihat spikes pada grafik data sensor. Setelah dilakukan penapisan, spikes dapat dihilangkan dan grafik terlihat lebih smooth (warna merah).

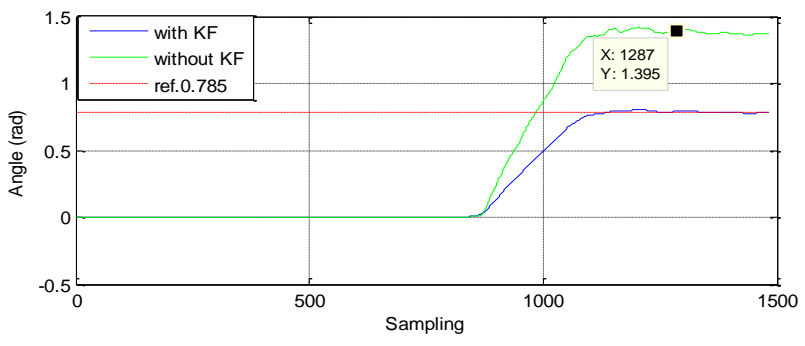

Gambar 12. Grafik Kecepatan Sudut $\omega_{\mathrm{x}}$ Rotasi $45^{\circ}$

Gambar 12 menunjukkan grafik hasil estimasi sudut orientasi $45^{\circ}(0,785$ rad $)$ terhadap aksis-X. Pengujian estimasi dilakukan menggunakan metode Kalman Filter (KF) dan metode integral langsung (tanpa KF). Dengan metode integral langsung, diperoleh hasil estimasi 1,395 rad $\left(79,93^{\circ}\right)$ dan dengan metode KF diperoleh hasil estimasi $0,802 \operatorname{rad}\left(45,95^{\circ}\right)$. Berdasarkan hasil pengujian ini, dapat dihitung akurasi metode integral langsung dan akurasi metode KF.

Hasil pengujian untuk estimasi sudut roll, pitch dan yaw dengan rotasi $0,785 \mathrm{rad}\left(45^{\circ}\right)$ selengkapnya dapat ditunjukkan pada Tabel 2. Pada Tabel 2, kolom Aktual adalah sudut yang ditentukan sebagai acuan estimasi dan kolom 'Estimasi' menunjukkan hasil estimasi metode integral langsung (TKF) dan KF.

Tabel 2. Estimasi Sudut Roll, Pitch, dan Yaw

\begin{tabular}{cccccc}
\hline \multirow{2}{*}{ Uji } & $\begin{array}{c}\text { Aktual } \\
\text { (rad) }\end{array}$ & \multicolumn{2}{c}{ Estimasi (rad) } & \multicolumn{2}{c}{ Akurasi (\%) } \\
\cline { 3 - 6 } Roll & 0,785 & TKF & KF & TKF & KF \\
\hline \hline Pitch & 0,785 & 1,431 & 0,802 & 22,29 & 97,83 \\
& & & & & \\
\hline Yaw & 0,785 & 1,406 & 0,799 & 20,89 & 98,60 \\
\hline
\end{tabular}

Sebagaimana dapat dilihat pada Tabel 2, hasil pengujian dengan metode integral langsung (TKF) menghasilkan akurasi 22,29\% untuk roll, 17,71\% untuk pitch dan 20,89 $\%$ untuk yaw. Sedangkan dengan metode KF, diperoleh hasil akurasi 97,83\% untuk roll, 96,82\% untuk pitch dan 98,60 $\%$ untuk yaw. Dari hasil pengujian ini, estimasi sudut orientasi menggunakan metode KF memiliki akurasi lebih baik dibanding dengan metode integral langsung. Berdasarkan pengamatan, penggunaan sensor yang berbeda dapat menghasilkan data yang berbeda. Hal ini mungkin disebabkan sensor yang digunakan dalam kategori low cost. Namun, secara umum model sistem mampu memberikan estimasi cukup akurat.

\subsection{Estimasi Pergerakan Translasi}

Data keluaran sensor akselerometer berupa data percepatan linear. Metode state space dan Kalman filter digunakan untuk mendapatkan estimasi pergerakan translasi dari masukan data percepatan linier. Dalam penelitian ini, data percepatan didapatkan dengan menggerakkan quadrotor secara linier pada arah X atau Y dengan kecepatan tertentu. Pengujian ini bertujuan untuk menguji model sistem dalam memberikan estimasi jarak pergeseran translasi arah $\mathrm{X}$ atau Y. Dalam kasus ini, arah $\mathrm{Z}$ yang berkaitan dengan arah ketinggian terhadap ground tidak diperhitungkan atau diabaikan dalam pengukuran.

Pengujian pergerakan translasi dilakukan dengan menggerakkan quadrotor diatas bidang XY dari keadaan diam pada koordinat $(\mathrm{X}, \mathrm{Y})=(0,0)$ menuju koordinat $(\mathrm{X}, \mathrm{Y})$ $=(2,-2)$ selama beberapa detik dengan kecepatan sembarang. Hasil pengujian ditunjukkan pada Gambar 13 sampai Gambar 16.

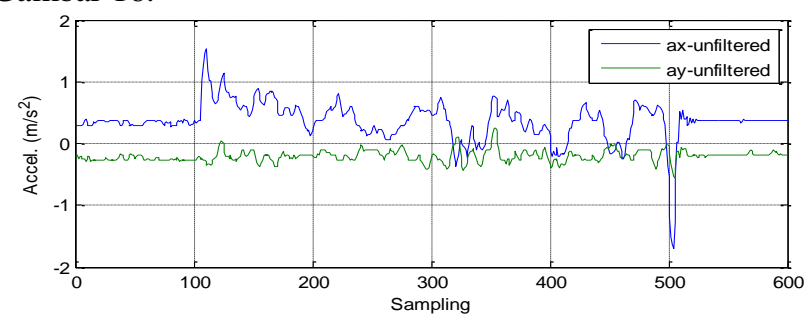

Gambar 13. Grafik Data Percepatan $a_{\mathrm{x}}$ dan $a \mathrm{y}$

Gambar 13 menunjukkan grafik percepatan $\left(\mathrm{m} / \mathrm{s}^{2}\right)$ saat saat sensor digerakkan pada bidang X-Y sebelum melewati filter. Data yang terbaca adalah kecepatan pada aksis-X dan aksis-y. Seperti terlihat pada Gambar 13, terlihat derau spikes dan kesalahan tegangan bias pada grafik. Hal ini dapat mempengaruhi hasil estimasi.

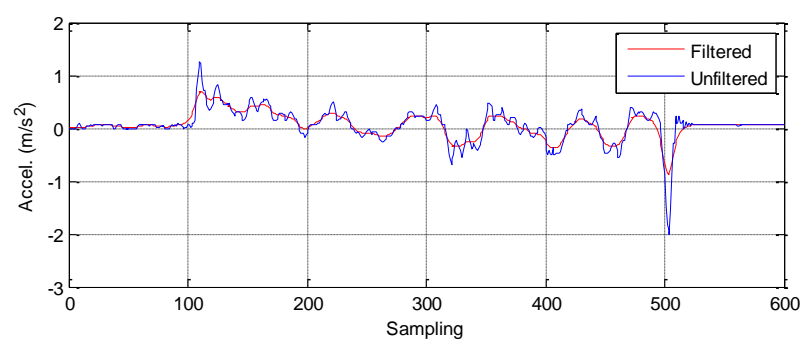

Gambar 14. Grafik Data Percepatan $a_{\mathrm{x}}$ 
Gambar 14 menunjukkan grafik percepatan pada aksis-X sebelum dan setelah melewati filter sebagai perbandingan. Setelah dilakukan penapisan, derau spikes dapat dikurangi sehingga grafik terlihat lebih smooth (warna merah). Selain itu, kesalahan tegangan bias juga sudah dibetulkan.

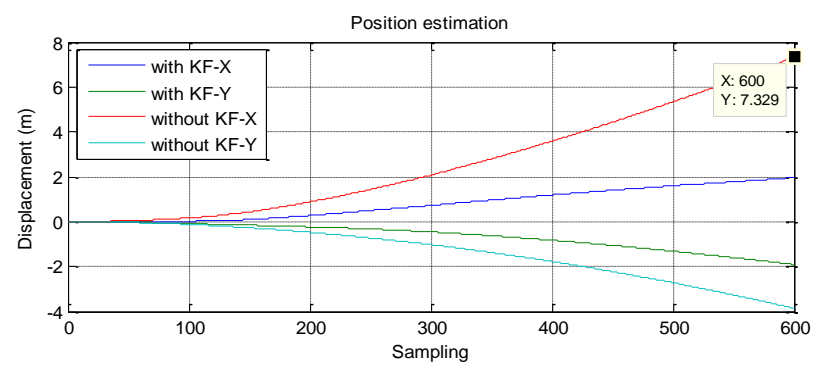

Gambar 15. Grafik Estimasi Posisi Pergerakan Translasi

Gambar 15 menunjukkan grafik estimasi jarak pergeseran translasi pada arah bidang X-Y. Pengujian estimasi dilakukan dengan menggunakan metode Kalman filter (KF) dan metode integral biasa (tanpa KF). Pada arah $\mathrm{X}$, diperoleh hasil estimasi 1,963 m dengan metode KF dan 7,329 $\mathrm{m}$ dengan metode integral biasa, dengan jarak sebenarnya adalah $2 \mathrm{~m}$. Sementara pada arah Y, diperoleh hasil estimasi -1,911 m dengan metode KF dan -3,855 m dengan metode integral biasa, dengan jarak sebenarnya adalah $-2 \mathrm{~m}$

Hasil pengujian gerakan translasi pada arah bidang $\mathrm{X}-\mathrm{Y}$ selengkapnya dapat ditunjukkan pada Tabel 3. Akurasi dihitung berdasarkan jarak aktual dibandingkan dengan hasil estimasi yang dinyatakan dalam persen.

Tabel 3. Estimasi Pergeseran pada Arah Bidang X-Y

\begin{tabular}{|c|c|c|c|c|c|c|}
\hline \multirow{2}{*}{$\begin{array}{c}\text { Aktual } \\
\text { (m) }\end{array}$} & \multirow{2}{*}{ Aksis } & \multicolumn{2}{|c|}{ Posisi akhir (m) } & \multicolumn{2}{|c|}{ Error $(m)$} & \multirow{2}{*}{$\begin{array}{c}\text { Akuras } \\
\text { KF (\%) }\end{array}$} \\
\hline & & $T K F$ & $K F$ & $T K F$ & $K F$ & \\
\hline 2 & $x$ & 7,329 & 1,963 & 5,329 & 0,037 & 96,30 \\
\hline-2 & $Y$ & $-3,855$ & $-1,911$ & 1,855 & 0,089 & 91,10 \\
\hline
\end{tabular}

Sebagaimana dapat dilihat pada Tabel 3, perbedaan hasil estimasi dengan metode integral biasa dan metode Kalman filter sangat jauh. Dengan demikian, akurasi metode KF pada arah bidang X sebesar $96,30 \%$ sedangkan akurasi pada arah bidang Y sebesar 91,10\%. Dengan melihat hasil ini, metode Kalman filter dapat memberikan estimasi pengukuran diatas $90 \%$ dan lebih akurat dibanding metode integral biasa.

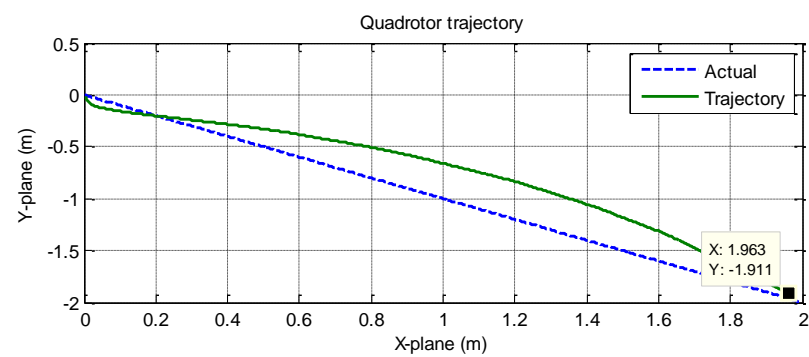

Gambar 16. Trajectory Quadrotor pada Bidang X-Y

Kemudian, Gambar 16 menunjukkan trajectory quadrotor pada bidang X-Y dengan Kalman filter. Seperti dapat dilihat pada Gambar 16, ada perbedaan antara kurva hasil estimasi dengan kurva referensi (actual). Hal ini bisa disebabkan gerakan sensor yang tidak sesuai dengan lintasan referensi karena peralatan pengujian yang kurang akurat. Waktu sampling data mungkin kurang cepat, sehingga data tidak dapat mewakili percepatan aktual secara akurat. Selain itu, karakteristik data sensor akselerometer tidak linier atau tidak konsisten dan data dari setiap aksis sensor tidak benarbenar independent.

\section{KeSimpulan}

Berdasarkan hasil pengujian, sensor IMU dengan Kalman filter sebagai sistem navigasi dapat memberikan estimasi sudut orientasi roll, pitch, yaw dengan akurasi yang dapat diterima setidaknya untuk waktu yang pendek. Model Kalman filter untuk estimasi jarak pergerakan translasi quadrotor mampu memberikan estimasi jarak pada arah $\mathrm{X}$ dan Y. Berdasarkan eksperimen dengan waktu pengambilan data beberapa detik, sistem dapat memberikan akurasi estimasi pengukuran diatas $90 \%$. Bila dibandingkan dengan metode integral langsung, Kalman filter dapat memberikan estimasi pengukuran lebih akurat. Sejauh ini, algoritma diujikan secara off-line, untuk aplikasi secara real-time, algoritma ini bisa memiliki beberapa keterbatasan. Pada penelitian selanjutnya, model dapat dikembangkan untuk dapat ditanamkan dalam embedded systems dan dapat diaplikasikan pada wahana secara real-time.

\section{UCAPAN TERIMA KASIH}

Penulis mengucapkan terima kasih kepada Laboratorium Instrumentasi dan Kendali DTETI UGM dan Dr. Eng. Adha Cahyadi atas dukungan dan bimbingan dalam penelitian ini.

\section{Daftar Pustaka}

[1] K. Schauwecker and A. Zell, "On-Board Dual-Stereo-Vision for Autonomous Quadrotor Navigation," in International Conference on Unmanned Aircraft Systems (ICUAS), pp. 333-342, 2013.

[2] K. D. Sebesta and N. Boizot, "A Real-Time Adaptive HighGain EKF , Applied to a Quadcopter Inertial Navigation System," IEEE Trans. Ind. Electron., vol. 61, no. 1, pp. 495503, 2014.

[3] B. J. Emran, M. Al-omari, M. F. Abdel-hafez, and M. A. Jaradat, "A Cascaded Approach for Quadrotor's Attitude Estimation," in Procedia Technology, , vol. 15, no. 971, pp. 268-277, 2014.

[4] S. Gupte and J. M. Conrad, "A survey of quadrotor Unmanned Aerial Vehicles," in Proceedings of IEEE Southeastcon, pp. 1-6, 2012.

[5] S. T. Goh, O. Abdelkhalik, and S. A. R. Zekavat, "A Weighted Measurement Fusion Kalman Filter implementation for UAV navigation," Aerosp. Sci. Technol., vol. 28, no., pp. 315-323, 2013.

[6] K. Benzemrane, G. Damm, and G. L. Santosuosso, "Adaptive Observer and Kalman Filtering," in Proceeding of the 17th World Coongress, The International Federation of Automatic Control, vol. 41, no. 2, pp. 3865-3870, 2008. 
[7] J. D. Barton, "Fundamentals of Small Unmanned Aircraft Flight," John Hopkins APL Tech. Dig., vol. 31, no. 2, pp. 132-149, 2012.

[8] B. Kada, K. Munawar, M. . Shaikh, and M. Hussaini, "UAV Attitude Estimaton Using Nonlinear Filtering and Low-Cost MEMS Sensor," IFAC-PapersOnLine, vol. 49, no. 21, pp. 521-528, 2016.

[9] R. Faragher, "Understanding the Basis of the Kalman Filter Via a Simple and Intuitive Derivation," IEEE Signal Process. Mag., vol. 29, no. September, pp. 128-132, 2012.

[10] N. Yadav and C. Bleakley, "Two Stage Kalman Filtering for Position Estimation Using Dual Inertial Measurement Units," in 2011 IEEE Sensors, pp. 1433-1436, 2011.

[11] M. Safitri and N.H. Wijaya, "Sistem Penapisan Derau pada Sensor Inersia Wahana Tanpa Awak Quadrotor," Jurnal SIMETRIS, vol. 7, no. 2, pp. 753-760, 2016.

[12] S. Shen, N. Michael, and V. Kumar, "Autonomous MultiFloor Indoor Navigation with a Computationally Constrained MAV," in IEEE International Conference on Robotics and Automation (ICRA), pp. 20-25, 2011.

[13] A. Bry, A. Bachrach, and N. Roy, "State Estimation for Aggressive Flight in GPS-Denied Environments Using Onboard Sensing," in IEEE International Conference on Robotics and Automation, pp. 1-8, 2012.

[14] W. Fei, C. Ben-mei, and L. E. E. T. H, “A Comprehensive UAV Indoor Navigation System Based on Vision Optical Flow and Laser Fast SLAM," Acta Autom. Sin., vol. 39, no. 11, pp. 1889-1899, 2013.

[15] Parrot, "http://www.parrot.com/global/drones/parrotardrone-20-power-edition\#technicals," di akses 3 September 2018.

[16] L. Lasmadi, "Attitude Estimation for Quadrotor Based On IMU With Kalman Filter," in SENATIK 2018, vol. IV, pp. 351-358, 2018. 